Egyptian Journal of Hospital Medicine (October 2020) Vol. 81 (7), Page 2416-2421

\title{
Study of The Role of Human Papilloma Virus and Laryngopharyngeal Reflux in Adult Vocal Fold Polyps
}

\author{
Abdelhakim Fouad Ghallab ${ }^{a}$, Ahmed Farag Allama ${ }^{a}$, Salwa Ahmed Abdelhay ${ }^{\text {, }}$ \\ Mohamed Gamal Abdelwahab ${ }^{\mathrm{c}}$, Rasha Abdelhamid Elsayed ${ }^{\mathrm{d}}$, Abdelrahman Ahmed Abdelalim ${ }^{\mathrm{a}, *}$ \\ ${ }^{a}$ Department of Otorhinolaryngology, ${ }^{\mathrm{b}}$ Unit of Phoniatrics, Department of Otorhinolaryngology, ${ }^{\mathrm{d}}$ Department of \\ Medical Microbiology and Immunology, Benha Faculty of Medicine, Benha University, ${ }^{\mathrm{c}}$ Department of \\ Otorhinolaryngology, Al-Ahrar Teaching Hospital, Ministry of Health and Population, Egypt. \\ Corresponding author: Mohamed Gamal Abdelwahab, Mobile: (+20) 01127123062, E-Mail: anashamza812@ gmail.com
}

\begin{abstract}
Background: There are several possible causes of vocal fold polyps in adults. The mechanical damage is the main cause for polyp formation. Laryngopharyngeal reflux and human papilloma virus are possible co-factors.

Objective: The aim of this study was to find out the associated roles of laryngopharyngeal reflux and human papilloma virus in the development of adult vocal fold polyps.

Patients and Methods: This cross-sectional observational study included 50 adult patients presented with vocal fold polyps. Patients were preoperatively assessed for the presence of laryngopharyngeal reflux using the validated nine-item reflux symptom index and eight-item reflux finding score. All patients were subjected to excision of the laryngeal polyp by microlaryngoscopic surgery. The excised samples were sent for human papilloma virus (HPV) detection by PCR.

Results: Laryngopharyngeal reflux (LPR) was presented in 34 patients (68\%). Reflux symptom index ranged from 6 to 25 (mean $13.06 \pm 4.95$ ). Reflux finding score ranged from 3 to 18 (mean $10.08 \pm 4.32$ ). Seventeen patients $(34 \%)$ had positive HPV-6. Fifteen patients had positive HPV-6 out of 34 patients diagnosed with LPR (44.11\%), compared to only two patients had positive HPV-6 among 16 patients without LPR $(12.5 \%)(\mathrm{P}=0.027)$. There were significant relations between presence of HPV-6 and both reflux symptom index and reflux finding score; both were significantly higher among patients with positive HPV-6 $(\mathrm{P}=0.028)$ and $(\mathrm{P}<0.001)$ respectively. Conclusion: Both laryngopharyngeal reflux and human papilloma virus play important associated roles in the development of vocal fold polyps in adults.
\end{abstract}

Keywords: Human papilloma virus; Laryngopharyngeal reflux; Vocal fold polyp.

\section{INTRODUCTION}

Adult vocal fold polyps are generally unilateral benign lesions affecting larynx, usually causing hoarseness of voice, breathiness and/or voice fatigue ${ }^{(\mathbf{1})}$. However, rare cases have been reported with large or giant polyps causing airway obstruction ${ }^{(2)}$.

The mechanical damage is the main cause for polyp formation either vocal over-and misuse or strong coughing. Smoking, gastroesophageal reflux, chronic/recurrent upper respiratory infections, and allergy are considered as co-factors ${ }^{(3)}$.

There are several possible causes of vocal fold polyps which can lead to increased vocal fold blood vessel permeability, local edema, hypoxia, degeneration, and fibrosis ${ }^{(4)}$. Laryngopharyngeal reflux (LPR) is an inflammatory condition of the upper aerodigestive tract related to effect of gastric or duodenal content reflux, which induces morphological changes in the upper aerodigestive tract ${ }^{(5)}$. The laryngopharynx is more susceptible than the esophagus to epithelial damage caused by reflux, since the laryngopharynx has a thin epithelium compared to the esophagus ${ }^{(6)}$. The higher prevalence of laryngopharyngeal reflux episodes in patients with benign true vocal fold lesions supporting the concept of a direct damaging effect of acidic gastric juice on the true vocal cords ${ }^{(7)}$.

Human papilloma viruses are species-specific viruses, which show strict tropism for the stratified squamous epithelium. Over 170 types have been identified so far that can infect the skin or the mucosal surface of the aerodigestive tract, those viruses can be classified as low-risk and high-risk types ${ }^{\left({ }^{(8)}\right.}$. Laryngeal papilloma can be developed and caused by the human papilloma virus (HPV), most commonly of low-risk subtypes 6 and 11, which infiltrates and proliferates within epithelial tissue. This condition can manifest in either childhood or adulthood ${ }^{(9)}$. The genotype HPV-11 appears to be associated with more severe forms, with an increased risk of airway obstruction ${ }^{(\mathbf{1 0})}$. However, only $20 \%$ of patients with laryngeal papilloma have measurable levels of human papilloma viral DNA ${ }^{(11)}$. Also, human papilloma virus can be latent in vocal folds without laryngeal papillomas and viral DNA can be detected by polymerase chain reaction (PCR) in the epithelium of the vocal cords in patients suffering from chronic laryngitis, nodules, or polyps reflecting the possible prevalence of latent HPV infections in the vocal cord mucosa ${ }^{(\mathbf{1 2})}$. 
We aimed in this study to find out the important roles of laryngopharyngeal reflux and human papilloma virus in the development of vocal fold polyps in adult patients and to study the possible association between LPR and HPV in adult vocal fold polyps.

\section{PATIENTS AND METHODS}

This study was carried out as a cross-sectional observational study at Benha University Hospital, Benha Faculty of Medicine, Benha, Egypt; during the period from May 2018 to August 2020. Fifty adult patients were included, suffering from hoarseness of voice due to presence of vocal fold polyp and presented to the outpatient clinic of the hospital.

We excluded from the study patients younger than 18 years, patients with history of laryngeal surgery, patients with history of laryngeal cancer, and/or patients with history of trauma to larynx.

Detailed history was obtained including the demographic data and history of the condition; onset, course, duration, frequency of exacerbations, and development of any complications. Full otorhinolaryngology examination of ear, nose, and throat was completed. Then examination of the larynx by video laryngostroboscopy was performed to detect the presence of laryngeal polyps and to document the physical findings of laryngopharyngeal reflux (LPR).

Subjectively, all patients were evaluated for the presence of symptoms of LPR such as intermittent dysphonia, vocal fatigue, voice breaks, chronic throat clearing, excessive throat mucus, chronic cough, and/or chronic airway obstruction. The nine-item reflux symptom index (RSI) was applied, it is a developed and validated questionnaire to quantify patient's symptoms of LPR and evaluate treatment efficacy. The scores of this questionnaire range from 0 (normal) to 45 (most severe). This validated questionnaire has displayed excellent reproducibility and criterion-based validity ${ }^{(\mathbf{1 3})}$.

Objectively, the laryngeal examination findings were recorded, the possible signs of LPR can range from vocal fold hyperemia or edema, subglottic edema or diffuse laryngeal edema, ventricular obliteration, posterior commissure hypertrophy and/or granuloma. The eight-item reflux finding score (RFS) was applied, it is a validated tool to document the physical findings severity of LPR. The scores of this tool range from 0 (normal) to 26 (most severe) ${ }^{(\mathbf{1 4})}$.

A score of reflux symptom index (RSI) greater than 13, or reflux finding score (RFS) above 7 points, were considered positive and clinically diagnostic and indicative of LPR ${ }^{(15,16)}$.

\section{Operative procedure:}

All patients were subjected to excision of the vocal fold polyp by direct microlaryngoscopy under general anesthesia. The excision samples were sent to microbiology department to search for human papilloma virus by polymerase chain reaction (PCR).

\section{Detection of HPV by PCR:}

Human papilloma virus genome detection was done by a multiplex PCR-based HPV typing assay using type-specific primers and agarose gel electrophoresis as described by Romero-Pastrana ${ }^{(17)}$.

\section{DNA extraction from paraffin sections:}

The formalin-fixed, paraffin-embedded (FFPE) tissue specimens from fifty patients were analyzed. After cutting deep into the block, eight $10 \mu \mathrm{m}$-sections of formalin-fixed paraffin embedded tissue were transferred to Eppendorf vials. Total DNA was extracted using QIAamp DNA FFPE Tissue (Qiagen, Hilden, Germany).

Deparaffinization of the sections were done by vortexing and incubation with xylene. Then xylene was decanted and its residue was removed by two pure ethanol washes. The air-dried pellet was then incubated for 10 hours with $25 \mu \mathrm{L}$ of proteinase $\mathrm{K}$ and $250 \mu \mathrm{L}$ of ATL lysis buffer in a heat block at $56^{\circ} \mathrm{C}$. The lysed emulsion was further purified with the spin-column kit. Finally, DNA was eluted in $50 \mu 1$ of AE buffer $(0.5 \mathrm{mM}$ EDTA) and then stored at $-20^{\circ} \mathrm{C}$ for further use.

\section{DNA amplification:}

Amplification was performed using forward primer (5'-ACG TGG CCT TGT GCG GTA CAG TC $\left.3^{\prime}\right)$ and reverse primer (5'-AGA GAC GAG TCA GGC AAT GC $\left.-3^{\prime}\right)$. The reaction was performed in a total volume of $25 \mu \mathrm{L}$ composed of $1 \mu \mathrm{L}$ of each primer, $5 \mu \mathrm{L}$ of extracted DNA, $12.5 \mu \mathrm{L}$ of Easy Taq ${ }^{\circledR}$ Universal PCR SuperMix (TransGen Biotech, Haidian District, Beijing, China), and $5.5 \mu \mathrm{L}$ of nuclease free water.

Amplification was done according to the protocol of: initial denaturation step at $95^{\circ} \mathrm{C}$ for $15 \mathrm{~min}$, 10 cycles of $30 \mathrm{~s}$ at $94^{\circ} \mathrm{C}, 90 \mathrm{~s}$ at $65^{\circ} \mathrm{C}$, and $90 \mathrm{~s}$ at $72^{\circ} \mathrm{C}$, followed by 30 cycles of $30 \mathrm{~s}$ at $94^{\circ} \mathrm{C}, 90 \mathrm{~s}$ at $63^{\circ} \mathrm{C}$, and $90 \mathrm{~s}$ at $72^{\circ} \mathrm{C}$, with a final extension at $72^{\circ} \mathrm{C}$ for $10 \mathrm{~min}$.

\section{Detection of PCR amplification products:}

The amplified samples were then run in on $2 \%$ agarose gel, in the presence of a DNA marker, using gel electrophoresis and visualized on a UV transilluminator to detect presence of amplified product and to type the HPV genome.

\section{Ethics and Consent:}

Informed written consent was obtained from all participants in the study. The study was performed in accordance with the Helsinki declaration and its amendments. The study protocol was approved by the Research Ethics Committee at Faculty of Medicine, Benha University (REC-FOMBU), Egypt. 
Statistical analysis

Obtained data were statistically analyzed using SPSS version 16 software (SPSS Inc, Chicago, IL, USA). "Chi-square test" was used to analyze categorical data, which were presented as number and percentage.
While "two sample t-test" was used to analyze quantitative data, which were presented as mean, standard deviation (SD), and range. $\mathrm{P}$-value $\leq 0.05$ was considered the accepted level of significance in this work.

\section{RESULTS}

The age, sex, and other findings in patients are shown in table 1 .

Table (1): Findings in total studied patients

\begin{tabular}{|c|c|c|}
\hline Variant & & Total patients- n (50) \\
\hline $\begin{array}{l}\text { Age (years): } \\
\text { Mean } \pm \mathrm{SD} \\
\text { (Range) }\end{array}$ & & $\begin{array}{c}38.940 \pm 5.180 \\
(30-52)\end{array}$ \\
\hline $\begin{array}{l}\text { Sex } \\
\text { Male } \\
\text { Female }\end{array}$ & $\mathrm{n}(\%)$ & $\begin{array}{l}22(44 \%) \\
28(56 \%)\end{array}$ \\
\hline $\begin{array}{c}\text { LPR } \\
\text { Absent } \\
\text { Present }\end{array}$ & $\mathrm{n}(\%)$ & $\begin{array}{l}16(32 \%) \\
34(68 \%)\end{array}$ \\
\hline $\begin{array}{l}\text { RSI } \\
\text { Mean } \pm \text { SD } \\
\text { (Range) }\end{array}$ & & $\begin{array}{c}13.060 \pm 4.950 \\
(6-25)\end{array}$ \\
\hline $\begin{array}{l}\text { RFS } \\
\text { Mean } \pm \text { SD } \\
\text { (Range) }\end{array}$ & & $\begin{array}{c}10.080 \pm 4.322 \\
(3-18)\end{array}$ \\
\hline $\begin{array}{l}\text { HPV-6 } \\
\text { Negative } \\
\text { Positive }\end{array}$ & $\mathrm{n}(\%)$ & $\begin{array}{l}33(66 \%) \\
17(34 \%)\end{array}$ \\
\hline $\begin{array}{l}\text { HPV-11 } \\
\text { Negative } \\
\text { Positive }\end{array}$ & n $(\%)$ & $\begin{array}{c}50(100 \%) \\
0(0 \%)\end{array}$ \\
\hline
\end{tabular}

HPV-6: human papilloma virus subtype 6; HPV-11: human papilloma virus subtype 11; LPR:

laryngopharyngeal reflux; RFS: reflux finding score; RSI: reflux symptom index

As shown in table 2, there was a statistically significant association between presence of LPR and HPV-6 genome detection.

Table (2): Comparison between laryngopharyngeal reflux present and absent cases

\begin{tabular}{|c|c|c|c|c|c|}
\hline \multirow{2}{*}{\multicolumn{2}{|c|}{ Variant }} & \multicolumn{2}{|c|}{ LPR } & \multicolumn{2}{|c|}{ Test } \\
\hline & & $\begin{array}{c}\text { Present } \\
\text { n (34) }\end{array}$ & $\begin{array}{l}\text { Absent } \\
\text { n (16) }\end{array}$ & $\chi^{2} / \mathrm{t}$ & $\begin{array}{c}P \\
\text { value }\end{array}$ \\
\hline \multicolumn{6}{|c|}{ Age (years): } \\
\hline & $\begin{array}{l}\text { Mean } \pm \text { SD } \\
\text { (Range) }\end{array}$ & $\begin{array}{c}39.323 \pm 5.649 \\
(30-52)\end{array}$ & $\begin{array}{c}38.125 \pm 4.047 \\
(33-47)\end{array}$ & 0.759 & 0.451 \\
\hline \multirow[t]{3}{*}{ Sex } & $\mathrm{n}(\%)$ & & & & \\
\hline & Male & $16(47.05)$ & $6(37.50)$ & \multirow{2}{*}{0.403} & \multirow{2}{*}{0.525} \\
\hline & Female & $18(52.94)$ & $10(62.50)$ & & \\
\hline \multirow[t]{3}{*}{ HPV-6 } & $\mathrm{n}(\%)$ & & & \multirow{3}{*}{4.847} & \multirow{3}{*}{0.028} \\
\hline & Negative & $19(55.88)$ & $14(87.50)$ & & \\
\hline & Positive & $15(44.11)$ & $2(12.50)$ & & \\
\hline
\end{tabular}

HPV-6: human papilloma virus subtype 6; LPR: laryngopharyngeal reflux

There was a statistically significant association between the presence of HPV -6 and both reflux severity index (RSI) and reflux finding score (RFS) (Table 3). 
Table (3): Comparison between HPV-6 negative and positive cases

\begin{tabular}{|c|c|c|c|c|}
\hline \multirow[t]{2}{*}{ Variant } & \multicolumn{2}{|c|}{ HPV-6 } & \multicolumn{2}{|c|}{ Test } \\
\hline & $\begin{array}{c}\text { Negative } \\
\text { n (33) }\end{array}$ & $\begin{array}{c}\text { Positive } \\
\text { n (17) }\end{array}$ & $\chi^{2} / \mathrm{t}$ & $\begin{array}{c}P \\
\text { value }\end{array}$ \\
\hline \multicolumn{5}{|l|}{ (years): } \\
\hline $\begin{array}{l}\text { Mean } \pm \text { SD } \\
\text { (Range) }\end{array}$ & $\begin{array}{c}39.151 \pm 4.981 \\
(30-52)\end{array}$ & $\begin{array}{c}38.529 \pm 5.680 \\
(32-49)\end{array}$ & 0.399 & 0.692 \\
\hline \multicolumn{5}{|l|}{$\mathrm{n}(\%)$} \\
\hline Male & $15(45.45)$ & 7 (41.17) & \multirow{2}{*}{0.083} & \multirow{2}{*}{0.773} \\
\hline Female & $18(54.54)$ & $10(58.82)$ & & \\
\hline \multicolumn{5}{|l|}{$\mathrm{n}(\%)$} \\
\hline Yes & $19(57.57)$ & $15(88.23)$ & \multirow{2}{*}{4.847} & \multirow{2}{*}{0.028} \\
\hline No & $14(42.42)$ & $2(11.76)$ & & \\
\hline $\begin{array}{l}\text { Mean } \pm \text { SD } \\
\text { (Range) }\end{array}$ & $\begin{array}{c}11.969 \pm 4.882 \\
(6-24)\end{array}$ & $\begin{array}{c}15.176 \pm 4.489 \\
(8-25)\end{array}$ & 2.258 & 0.028 \\
\hline $\begin{array}{l}\text { Mean } \pm \text { SD } \\
\text { (Range) }\end{array}$ & $\begin{array}{c}8.636 \pm 3.879 \\
(3-16)\end{array}$ & $\begin{array}{c}12.882 \pm 3.805 \\
(5-18)\end{array}$ & 3.689 & 0.0006 \\
\hline
\end{tabular}

HPV-6: human papilloma virus subtype 6; LPR: laryngopharyngeal reflux; RFS: reflux finding score; RSI: reflux symptom index

\section{DISCUSSION}

The latent and subclinical infections of human papillomavirus (HPV) have gained more interest, yet there is little information about the prevalence of latent HPV infections in the larynx ${ }^{(\mathbf{1 2})}$. It is clear that low-risk HPV infection is the predominant causative agent of juvenile laryngeal papillomatosis, but in adult-onset laryngeal papilloma, the condition is usually multifactorial ${ }^{(3,18)}$. On the other hand, the vocal fold mucosa in adult patients without papillomas (without morphological evidence of a HPV-associated lesion), but suffering chronic laryngitis, vocal cord nodules, or polyps could have detectable human papilloma viral genome by PCR ${ }^{(12)}$.

Chronic laryngeal irritation, irrespective of the specific irritant, may lead to morphologic changes in the larynx including polyp formation. Laryngopharyngeal reflux (LPR) irritates the laryngopharyngeal mucosa causing symptoms and signs of chronic reflux laryngitis. The prevalence of LPR has been constantly increasing nowadays affecting high percentage of the general population ${ }^{(7)}$.

The study of Formánek et al. ${ }^{(19)}$, stated that the LPR might be a risk factor for adult laryngeal papilloma or polyps by activating or reactivating a latent HPV infection. They recommended additional studies with larger cohorts to confirm their findings and to clear up the mechanisms involved. The aim of the present work was to study the important roles of laryngopharyngeal reflux and human papilloma virus in the development of adult vocal fold polyps and to study the possible association between LPR and HPV in this entity through assessment of the prevalence of human papillomavirus (HPV) in patients presented with adult vocal fold polyp and suffering from laryngopharyngeal reflux (LPR).

In the present study, we included 50 patients with adult focal fold polyps, the age of patients ranged from 30 to 52 years with a mean age of $38.94 \pm 5.18$ years, twenty-eight of the patients were females $(56 \%)$ and 22 were males (44\%). This matches with Martins et $\boldsymbol{a l} .{ }^{(20)}$ who studied the clinical and morphological characteristics of 76 patients with vocal fold polyps and found that the age ranged between 21 and 60 years with male to female ratio represented $43 \%$ to $57 \%$. Our results also matches with Yun $\boldsymbol{e t}$ al. ${ }^{\left({ }^{(21)}\right.}$ who studied 175 patients with vocal fold polyps, $58.8 \%$ were female and $41.2 \%$ were male, their age ranged between 24 to 78 years. This means that adult vocal fold polyps do occur in a wide age range and not gender related.

In the present study, the prevalence of laryngopharyngeal reflux (LPR) among the patients with adult vocal fold polyp was (68\%) and was not related to age or gender. This goes in line with the studies of Beltsis et al. ${ }^{(7)}$ and Chung et al. ${ }^{(22)}$, both used $\mathrm{pH}$ monitoring for diagnosis of the reflux and both studies found that LPR presented in $(75 \%)$ of patients with true adult vocal fold polyps. Also, Wang et al. ${ }^{(23)}$ 
who studied 32 patients submitted to laryngeal surgery for vocal polyps, revealed a significantly higher presence of pepsin (75\%) in patients with vocal polyps when compared with the control group (31.25\%).

In our study we used the reflux symptom index (RSI) and the reflux finding score (RFS) as clinically non-invasive simple diagnostic tools of LPR. Although 24-h double-probe ambulatory $\mathrm{pH}$ monitoring is considered the gold standard for LPR diagnosis, but number of studies have been able to validate the RSI and RFS assessments as diagnostic tests of LPR ${ }^{(14,16,24)}$.

Regarding HPV genome detection, we found 17 samples representing (34\%) of the studied patients had positive HPV-6 while no one $(0 \%)$ had positive HPV-11. Our results were higher than Rihkanen et al. (12) who detected the virus in the epithelium of (19\%) of patients operated for chronic laryngitis, nodules, and polypi without laryngeal papillomas. The prevalence of HPV in our study was comparable to previous studies on adult papillomas as Makiyama et al. ${ }^{(25)}$ who found that $(46.1 \%)$ of patients with adult laryngeal papilloma were positive for HPV-6 and (7.6\%) were positive for HPV-11, but their study included relatively smaller number of participants (13 patients). Hirai et al. ${ }^{(26)}$ found a higher prevalence of low-risk HPV (66.7\%) in adult patients with laryngeal papillomas. The fact that we found the rates of occurrence of the virus in cases of polyps approximates to some extent the rates of occurrence in cases of adult papillomas, this indicates the presence of latent virus in the laryngeal mucosa.

From the results of our study, it seems that there is a strong relation and association between detection of HPV-6 genome and LPR in cases with adult vocal fold polyps. Laryngopharyngeal reflux was present in 15 out of $17(88.23 \%)$ patients with positive HPV-6. Supporting this association in the present study, there were statistically significant higher reflux severity index (RSI) and reflux finding score (RFS) among patients with positive HPV-6. Formánek et al. ${ }^{(19)}$ noted the association between the laryngopharyngeal reflux (pepsin in tissue) and human papilloma virus detection in adult laryngeal papilloma. They studied 20 recurrent cases of vocal papilloma, HPV was found in all of the biopsies, and pathologic LPR was diagnosed in $(40.0 \%)$, therefore they might be possible risk factors for this disease.

Previous studies suggested a link between the presence of extraesophageal acid reflux disease and recurrent respiratory papillomatosis in children ${ }^{(27,28)}$. They hypothesized that the inflammation induced by chronic acid exposure may result in the expression of HPV in susceptible tissues. Our findings in adult vocal fold polyps regarding the significant detection of HPV6 genome in $(44.11 \%)$ of patients with LPR, support this hypothesis in adults. Laryngopharyngeal reflux may be one of the factors which lead to human papilloma virus activation. The detection of HPV genome in the excision biopsies of adult vocal fold polyps may be useful as an etiological factor particularly if associated with symptoms and signs of laryngopharyngeal reflux.

\section{CONCLUSION}

Both laryngopharyngeal reflux and human papilloma virus play important roles in the development of vocal fold polyps in adults and there is a possible association between LPR and HPV in this entity as the prevalence of human papillomavirus (HPV) in patients presented with adult vocal fold polyp and suffering from laryngopharyngeal reflux (LPR) was significantly higher than that in patients not suffering LPR. There were statistically significant higher reflux severity index (RSI) and reflux finding score (RFS) among patients with positive HPV-6.

Based on these findings and results, future studies are recommended in the direction of possible adjuvant antiviral therapy after excisions of adult vocal fold polyps particularly if associated with symptoms and signs of laryngopharyngeal reflux.

Funding sources: This research did not receive any specific grant from funding agencies in the public, commercial, or not-for-profit sectors.

Conflict of interest: The authors declare no conflict of interest.

Availability of data and material: The data that support the findings of this study are available from the corresponding author upon reasonable request.

\section{REFERENCES}

1. Vasconcelos D, Gomes A, Araújo C (2019): Vocal fold polyps: Literature review. Int Arch Otorhinolaryngol., 23(1):116-124.

2. Kusunoki T, Fujiwara R, Murata $\mathrm{K}$ et al. (2009): A giant vocal fold polyp causing dyspnea. Ear Nose Throat J., 88(12):1248-9.

3. Nunes R, Behlau M, Nunes $M$ et al. (2013): Clinical diagnosis and histological analysis of vocal nodules and polyps. Braz J Otorhinolaryngol., 79(4):434-40.

4. Bohlender J (2013): Diagnostic and therapeutic pitfalls in benign vocal fold diseases. GMS Curr Top Otorhinolaryngol Head Neck Surg., 12:1-6.

5. Lechien J, Saussez S, Nacci A et al. (2019): Association between laryngopharyngeal reflux and benign vocal folds 


\section{https://ejhm.journals.ekb.eg/}

lesions: A systematic review. Laryngoscope, 129(9):329341.

6. Axford S, Sharp N, Ross P et al. (2001): Cell biology of laryngeal epithelial defenses in health and disease: preliminary studies. Ann Otol Rhinol Laryngol., 110(12):1099-108.

7. Beltsis A, Katsinelos P, Kountouras $\mathrm{J}$ et al. (2011): Double probe $\mathrm{pH}$-monitoring findings in patients with benign lesions of the true vocal folds: comparison with typical GERD and the effect of smoking. Eur Arch Otorhinolaryngol., 268(8):1169-1174.

8. Donà M, Pichi B, Rollo $\mathbf{F}$ et al. (2017): Mucosal and cutaneous human papillomaviruses in head and neck squamous cell papillomas. Head Neck, 39(2):254-259.

9. Fortes H, von Ranke F, Escuissato D et al. (2017): Recurrent respiratory papillomatosis: A state-of-the-art review. Respir Med., 126:116-121.

10. Ilboudo M, Zohoncon T, Traore I et al. (2019): Implication of low risk human papilloma viruses, HPV6 and HPV11 in laryngeal papillomatosis in Burkina Faso. Am J Otolaryngol., 40(3):368-371.

11. McClay J (2016): Medicine Medscape, Drugs \& Diseases, Otolaryngology and Facial Plastic Surgery, Recurrent respiratory papillomatosis surgery. Available from: https://emedicine.medscape.com/article/865758overview.

12. Rihkanen H, Peltomaa J, Syrjänen S (1994): Prevalence of human papillomavirus (HPV) DNA in vocal cords without laryngeal papillomas. Acta Otolaryngol., 114(3):348-51.

13. Belafsky P, Postma G, Koufman J (2002): Validity and reliability of the reflux symptom index (RSI). J Voice, 16(2):274-7.

14. Belafsky P, Postma G, Koufman J (2001): Laryngopharyngeal reflux symptoms improve before changes in physical findings. Laryngoscope, 111(6):97981.

15. Mesallam T, Stemple J, Sobeih T et al. (2007): Reflux symptom index versus reflux finding score. Ann Otol Rhinol Laryngol., 116(6):436-40.

16. Nunes H, Pinto J, Zavanela A et al. (2016): Comparison between the Reflux Finding Score and the Reflux Symptom Index in the Practice of Otorhinolaryngology. Int Arch Otorhinolaryngol., 20(3):218-21.
17. Romero-Pastrana F (2012): Detection and typing of human papilloma virus by multiplex PCR with typespecific primers. ISRN Microbiol., 2012:186915.

18. Li J, Zhang T, Tan L et al. (2015): Expression of human papillomavirus and prognosis of juvenile laryngeal papilloma. Int J Clin Exp Med., 8(9):15521-7.

19. Formánek M, Jančatová $D$, Komínek $P$ et al. (2017): Laryngopharyngeal reflux and herpes simplex virus type 2 are possible risk factors for adult-onset recurrent respiratory papillomatosis (prospective case-control study). Clin Otolaryngol., 42(3):597-601.

20. Martins R, Defaveri J, Domingues $M$ et al. (2011): Vocal polyps: clinical, morphological, and immunohistochemical aspects. J Voice, 25(1):98-106.

21. Yun Y, Kim M, Son Y (2007): The effect of vocal hygiene education for patients with vocal polyp. Otolaryngol Head Neck Surg., 137(4):569-75.

22. Chung J, Tae K, Lee Y et al. (2009): The significance of laryngopharyngeal reflux in benign vocal mucosal lesions. Otolaryngol Head Neck Surg., 141(3):369-73.

23. Wang L, Tan J, Wu T et al. (2017): Association between laryngeal pepsin levels and the presence of vocal fold polyps. Otolaryngol Head Neck Surg., 156(1):144-151.

24. Merati A, Lim H, Ulualp S et al. (2005): Meta-analysis of upper probe measurements in normal subjects and patients with laryngopharyngeal reflux. Ann Otol Rhinol Laryngol., 114(3):177-82.

25. Makiyama K, Hirai R, Matsuzaki H et al. (2013): Assessment of human papilloma virus infection in adult laryngeal papilloma using a screening test. J Voice, 27(2):230-5.

26. Hirai $\mathrm{R}$, Makiyama $\mathrm{K}$, Higuti $\mathrm{Y}$ et al. (2012): Pharyngeal squamous cell papilloma in adult Japanese: comparison with laryngeal papilloma in clinical manifestations and HPV infection. Eur Arch Otorhinolaryngol., 269(10):2271-6.

27. Borkowski G, Sommer P, Stark T et al. (1999): Recurrent respiratory papillomatosis associated with gastroesophageal reflux disease in children. Eur Arch Otorhinolaryngol., 256(7):370-2.

28. McKenna M, Brodsky L (2005): Extraesophageal acid reflux and recurrent respiratory papilloma in children. Int J Pediatr Otorhinolaryngol., 69(5):597-605. 